\title{
Student Perceptions Of The Online "Classroom": An Update
}

John R. Tanner, (E-mail: jrt4671@louisiana.edu), University of Louisiana at Lafayette Thomas C. Noser, Western Kentucky University

Michael W. Totaro, University of Louisiana at Lafayette

Rachelle Birch, University of Louisiana at Lafayette

\begin{abstract}
In this paper, the authors compare perceptions of 2001-2002 undergraduate students toward online courses, with the attitudes of undergraduate students matriculating in 2005. Specifically, a questionnaire developed and used in a study during the period 2001-2002, in which there were eight hundred ninety-six (896) undergraduate students at two medium-sized southern universities, was again given to six hundred twenty-six (626) undergraduate students at these same two universities in 2005. The results suggest that students continue to have questions about the overall appeal of online courses, despite the fact that three to four years have elapsed. The results of this study should be of interest to university administrators, faculty members, and students who plan to offer, teach, or take online courses in the future. This information may be helpful to university administrators in deciding which types of courses at their universities might be offered online. Faculty who are considering teaching one or more online courses may find the results of this study helpful in structuring these online offerings. This research is also intended to give students a realistic expectation of what to anticipate from online courses, based upon information we have found and studies we have done.
\end{abstract}

\section{BACKGROUND AND LITERATURE REVIEW}

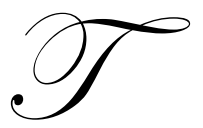

he number of online, or distance learning, course offerings continues to increase at colleges and universities. The growing popularity of this medium for instruction is due to a combination of factors. The economic advantages of distributing scarce resources, geographically and temporally, to students in remote locations provide a broader market for distance education. Additionally, the increasing demand from students to acquire education at times that are convenient, given their busy schedules and personal commitments, makes distance education attractive to working learners (Roberts, 1998). This, of course, enables students to create an atmosphere for learning at home.

Distance learning can be defined as instruction not bound by time or place. Two forms, or modes, of distance learning exist: asynchronous and synchronous. The asynchronous form of distance learning removes the physical and time constraints for the teacher as well as the student; that is, the teacher and students are not necessarily "online" at the same time. In contrast, the synchronous form of distance learning involves having the teacher and students online concurrently. Distance learning can be defined more formally as any course delivered with tools or technologies designed to overcome the restrictions of either same-time or same-place learning. In traditional education, "brick and mortar" limit enrollments. Such limitations cannot easily be corrected in the short run. However, with distance education and the appropriate technology, it is technically possible for an institution located in one locale to have many of its students located in remote locations hundreds of miles away (Daniel, 1997; Lewis, Alexander and Farris, 1997).

The distance debate usually focuses on issues related to student learning and outcomes and student attitudes as compared to traditional classroom-based settings (Phillips, 1998; Webster and Hackley, 1997). One interesting study, through the application of expectancy theory, identified that, on average, students consider improving competence in performing course work as the most attractive outcome of a distance-learning class (Chen, Lou, and 
Luo, 2001). Using a meta-analysis approach, one group of researchers found considerable support for the premise that distance education does not diminish the level of student satisfaction when compared to methods of instruction that use the more traditional face-to-face approach (Allen, Bourhis, Burrell, and Mabry, 2002). One survey found that most first year information technology majors and financial information systems majors perceived learning to be more fun and of better quality within a technology-enhanced distance learning environment (Parker, 2003). Finally, the results of another study reveal that self-management, self-reliance, and accurate expectations of learner responsibilities are significant attributes for a successful distance-learning (primarily web-based) experience (Howland and Moore, 2002).

For the institution, distance-learning programs can initially be expensive and time consuming. For the instructor, the first crucial step is choosing a type of instruction that is designed for the new paradigm of distance learning. This is then followed by the transformation of traditional education techniques to the new methodology. Students must also change their focus when in distance education. The students not only need traditional printed material, such as textbooks or other reading, but also must have access to and a working knowledge of web-based technology, including the Internet, e-mail, chat rooms and bulletin boards. Distance learning courses offer significant differences from the classic classroom environment. There is no face-to-face contact, no context clues, and no opportunity for immediate dyadic communication. In the first few weeks of the course, students usually feel high anxiety due to the uncertainty of what the professor really wants and, as a result, the professor is bombarded with emails. When both the professor and the student get comfortable with this new environment real learning can take place. This analysis focuses on the student and his/her perception of the online education experience.

The purpose of this paper is to compare perceptions of 2001-2002 undergraduate students toward online courses, with the attitudes of undergraduate students matriculating in 2005. Distance education has grown substantially in the past three to four years, and it is expected that students' attitudes toward online courses might have changed as well. The results of this study should also be of interest to university administrators, faculty members, and students who plan to offer, teach, or take online courses in the future. Since many universities are still in the early stages of deciding whether to offer such courses, this information may be helpful to university administrators in deciding which types of courses at their universities might be offered online. Faculty who are considering teaching one or more online courses may find the results of this study helpful in structuring these online offerings. The results of this study should assist students in gaining a realistic expectation of what to anticipate from distance learning courses based on information we have found and studies we have done. It is important that students have a realistic perception of the distance learning experience.

\section{METHODOLOGY}

A questionnaire developed and used in a study during the period 2001-2002 (Tanner, Langford, Walker, 2001; Tanner, Noser, Fuselier, Totaro, 2004), in which there were eight hundred ninety-six (896) undergraduate students at two medium-sized southern universities, was again given to six hundred twenty-six undergraduate students at these same two universities in 2005. In the first study, one hundred ninety (190) students had taken online courses, and seven hundred three (703) had not, with three (3) non-respondents. In the second study, one hundred ninety-nine (199) students had taken an online class, and four hundred twenty-five (425) had not, with two (2) non-respondents, which was not a significant increase. In both studies, the students' participation was completely voluntary and anonymous, although most students opted to respond. Thus, the respondents were basically a convenience sample. In addition to demographic questions on gender, age, grade-point average, enrollment status, classification, and whether or not they had ever taken a course online, students were also asked to respond to sixteen (16) Likert-type questions concerning online courses and related statements with which they could express various levels of agreement or disagreement $(1=$ Strongly Agree; $2=$ Agree; $3=$ Neither Agree nor Disagree; $4=$ Disagree; $5=$ Strongly Disagree $)$.

\section{RESULTS}

Table 1 provides a demographic profile of all respondents. As the table shows, the 2001-2002 study had more female than male respondents, while the 2005 study had slightly more males. In both groups, the majority of respondents were aged 21 or less. The mean grade-point average was 3.051 for the 2001-2002 respondents, and 3.153 
for the 2005 respondents. In both groups, almost all respondents were full-time students, with more than 64 percent of the 2001-2002 respondents classified as juniors or seniors, and more than 58 percent of the 2005 respondents classified as juniors or seniors. More than 60 percent of the 2001-2002 students were business majors, while 67 percent of the 2005 students were majoring in business. More than 21 percent of the 2001-2002 respondents had taken an online course, while slightly less than 32 percent of the 2005 respondents had taken an online course, an increase that is noteworthy, but not statistically significant.

Table 1: Demographic Profiles Of 2001-2002 Student Respondents (N=896) And 2005 Respondents (N=626)

\begin{tabular}{|c|c|c|}
\hline Demographic Variables & $\begin{array}{l}\text { Percent of 2001-2002 } \\
\text { Respondents }(\mathrm{n}=896) \\
\end{array}$ & $\begin{array}{l}\text { Percent of } 2005 \text { Respondents } \\
(n=626)\end{array}$ \\
\hline \multicolumn{3}{|l|}{ Gender: } \\
\hline Males & $46.6 \%$ & $51.3 \%$ \\
\hline Females & $53.4 \%$ & $48.7 \%$ \\
\hline \multicolumn{3}{|l|}{ Age Groups: } \\
\hline 21 or less & $67.3 \%$ & $69.1 \%$ \\
\hline Over 21 & $32.7 \%$ & $30.9 \%$ \\
\hline Mean Grade-point Average: & 3.051 & 3.153 \\
\hline \multicolumn{3}{|l|}{ Enrollment Status: } \\
\hline Part-time & $3.2 \%$ & $4.6 \%$ \\
\hline Full-time & $96.8 \%$ & $95.4 \%$ \\
\hline \multicolumn{3}{|l|}{ Classification: } \\
\hline Freshman & $9.8 \%$ & $9.2 \%$ \\
\hline Sophomore & $26.0 \%$ & $32.4 \%$ \\
\hline Junior & $32.7 \%$ & $35.6 \%$ \\
\hline Senior & $31.5 \%$ & $22.8 \%$ \\
\hline \multicolumn{3}{|l|}{ Major: } \\
\hline College of Business Major & $60.2 \%$ & $67.0 \%$ \\
\hline Non-College of Business Major & $39.8 \%$ & $33.0 \%$ \\
\hline \multicolumn{3}{|c|}{ Have You Taken an Online Course Before? } \\
\hline Yes & $21.3 \%$ & $31.9 \%$ \\
\hline No & $78.7 \%$ & $68.1 \%$ \\
\hline
\end{tabular}

\section{COMPARISONS OF 2001-2002 AND 2005 STUDENT PERCEPTIONS}

Table 2 presents the results of significance tests between the average perceptions of the 2001-2002 respondents toward online course offerings and related statements with the perceptions of the 2005 respondents to the same Likert-type statements. 
Table 2: Results Of Comparisons Of Attitudes Of 2001-2002 Students Vs. 2005 Students Toward Online Course Offerings And Related Statements

\begin{tabular}{|c|c|c|c|c|c|c|}
\hline \multirow[t]{2}{*}{ Likert Statements } & \multicolumn{2}{|c|}{ Mean Responses* } & \multicolumn{2}{|c|}{ Standard Deviations } & \multirow[t]{2}{*}{ t-stat } & \multirow[t]{2}{*}{ p-value } \\
\hline & $\begin{array}{c}\text { 2001- } \\
2002 \\
\text { Students } \\
\end{array}$ & $\begin{array}{c}2005 \\
\text { Students }\end{array}$ & $\begin{array}{c}2001- \\
2002 \\
\text { Students } \\
\end{array}$ & $\begin{array}{c}2005 \\
\text { Students }\end{array}$ & & \\
\hline $\begin{array}{l}\text { 1. One of the advantages of taking a course } \\
\text { online is that class times are flexible. }\end{array}$ & 1.88 & 1.87 & 1.02 & 1.08 & 0.104 & .917 \\
\hline $\begin{array}{l}\text { 2. I believe that a class in liberal arts, such as } \\
\text { history, psychology, sociology, etc., would } \\
\text { work well if offered online. }\end{array}$ & 2.72 & 2.79 & 1.22 & 1.25 & -1.039 & .299 \\
\hline $\begin{array}{l}\text { 3. The interaction/lecture with the instructor } \\
\text { is greater in a regular classroom setting than } \\
\text { in an online class. }\end{array}$ & 2.12 & 2.09 & 1.15 & 1.11 & 0.485 & .628 \\
\hline $\begin{array}{l}\text { 4. Math and other quantitative courses are } \\
\text { among the most difficult of all my college } \\
\text { courses. }\end{array}$ & 2.55 & 2.53 & 1.37 & 1.36 & 0.281 & .779 \\
\hline $\begin{array}{l}\text { 5. I believe taking a course online allows } \\
\text { studying at your own pace. }\end{array}$ & 2.23 & 2.26 & 1.03 & 1.06 & -0.561 & .575 \\
\hline $\begin{array}{l}\text { 6. In my opinion, management courses } \\
\text { should not be offered online. }\end{array}$ & 3.10 & 3.24 & 1.03 & 1.06 & -2.593 & $.010 * *$ \\
\hline $\begin{array}{l}\text { 7. Meeting with other students outside of } \\
\text { class is important to me. }\end{array}$ & 2.82 & 2.98 & 1.14 & 1.12 & -2.781 & $.005 * *$ \\
\hline $\begin{array}{l}\text { 8. I would take a statistics or other } \\
\text { quantitative class online if it was offered. }\end{array}$ & 3.31 & 3.39 & 1.28 & 1.33 & -1.137 & .256 \\
\hline $\begin{array}{l}\text { 9. The fact that in an online class there is no } \\
\text { structured classroom-type environment } \\
\text { appeals to me. }\end{array}$ & 2.79 & 2.79 & 1.04 & 1.16 & -0.126 & .900 \\
\hline $\begin{array}{l}10 . \text { In the future, I will take as many courses } \\
\text { as possible online. }\end{array}$ & 3.13 & 3.23 & 1.15 & 1.20 & -1.479 & .139 \\
\hline $\begin{array}{l}\text { 11. I would miss the interaction with other } \\
\text { students in an online class. }\end{array}$ & 2.63 & 2.70 & 1.17 & 1.17 & -1.142 & .264 \\
\hline $\begin{array}{l}\text { 12. The textbook is more important in an } \\
\text { online class. }\end{array}$ & 2.38 & 2.27 & 1.08 & 1.08 & 1.846 & .065 \\
\hline 13. Tests in an online class are more difficult. & 2.95 & 2.90 & 0.74 & 0.86 & 1.242 & .215 \\
\hline $\begin{array}{l}\text { 14. Online classes require the students to } \\
\text { teach themselves the material. }\end{array}$ & 2.20 & 2.12 & 0.98 & 0.95 & 1.646 & .100 \\
\hline $\begin{array}{l}\text { 15. The technology required to take an online } \\
\text { course increases the value of the experience. }\end{array}$ & 2.66 & 2.74 & 0.95 & 0.95 & -1.618 & .106 \\
\hline $\begin{array}{l}\text { 16. Online classes require the student to be } \\
\text { self-disciplined. }\end{array}$ & 1.76 & 1.43 & 1.04 & 1.05 & 0.432 & .666 \\
\hline
\end{tabular}

*1 = Strongly Agree; 2 = Agree; 3 = Neither Agree nor Disagree; 4 = Disagree; 5 = Strongly Disagree

***Significant at .05 or less level

While these Likert questions are shown in the table (Table 2) in the order in which they appeared on the survey instrument, the questions could conceivably be categorized using the following scheme shown below, and will be discussed in this order:

- Questions/statements related to course/subject areas: \#2, \#4, \#6, \#8

- $\quad$ Online course structure: \#1, \#5, \#9, \#14, \#16

- $\quad$ Student and/or teacher interaction: \#3, \#7, \#11

- $\quad$ Materials/tests and technology: \#13, \#15

- $\quad$ Future online participation: \#10

As the results of the t-test between the 2001-2002 respondents and the 2005 respondents show, both groups exhibited the same level of agreement with the statement that a liberal arts class (such as history, psychology, sociology, etc.) would work well if offered online (Statement \#2). However, when asked if they felt that management 
courses should not be offered online, both groups disagreed, but the 2005 respondents showed a significantly stronger level of disagreement than did the 2001-2002 respondents (Statement \#6). This may be due in part to the fact that more business schools are offering management and other similar courses online each semester. Thus, the 2005 respondents might have had a greater opportunity to have taken such courses, or have friends who have done so, and thus might be more comfortable with the online concept as it applies to management classes.

Both groups also agreed that math and other quantitative courses were among the most difficult of all their college courses (Statement \#4). Not surprisingly, then, both groups of respondents disagreed that they would take a statistics or other similar quantitative course online if offered (Statement \#8). Thus, with respect to the statements related to online course/subject areas, with one exception, both the 2001-2002 and the 2005 respondents felt basically the same.

With respect to course structure, both groups showed the same strong level of agreement with the statement that an advantage of online courses is the flexible class times (Statement \#1). Similarly, both groups had about the same level of agreement with the statement that online courses allow students to study at their own pace (Statement \#5) and with the statement that the absence of a structured classroom-type environment appealed to them (Statement 9). Both groups also agreed that online classes basically require students to teach themselves the material (Statement \#14), and that online classes require self-discipline of the students (Statement \#16). Thus, with respect to statements related to online course structure, it is safe to say that both groups of respondents exhibited essentially the same level of agreement with all statements.

Concerning those Likert-type statements related to student and/or teacher interaction, both groups of respondent had similar levels of agreement that the interaction with the instructor is greater in an traditional class than in an online class (Statement \#3), and that they would miss the classroom interactions with other students if they took an online class (Statement \#11). While both the 2001-2002 and the 2005 student respondents agreed that meeting with other students outside class was important, the 2001-2002 respondent had a significantly higher level of agreement than the 2005 students, who in fact were almost neutral in their response to this statement (Statement \#7).

When asked about the relative difficulty of tests in an online course (Statement \#13), both groups had the same slight level of agreement. Also, both groups agreed that the technology required to take an online class enhances the experience (Statement \#15). Lastly, with respect to whether they would take an online class or classes in the future (Statement \#10), both groups exhibited about the same average level of disagreement. Thus, while there are many aspects of distance education or online courses upon which both the 2001-2002 and the 2005 respondents have similar perceptions, it would appear that, in the four years since the first study was done, students still have some questions about the complete appeal of such courses. Clearly, both groups believe that the class time flexibility afforded by online courses is advantageous, adding to the appeal of such offerings. However, the fact (or perception) that online classes require the students to teach themselves the material, and require them to be self-disciplined - and both groups agree with these positions-may contribute to online offerings being viewed as less than desirable. So while the number of online courses available to students has grown significantly over the last four years, it appears that students' perceptions of those offerings have not significantly changed.

\section{SUMMARY AND CONCLUSIONS}

Since the purpose of this paper is to compare perceptions of 2001-2002 undergraduate students toward online courses, with the attitudes of undergraduate students matriculating in 2005 , we shall recap the results of our comparisons.

With one exception, both the 2001-2002 and the 2005 respondents feel roughly the same for statements related to online course/subject areas. Regarding statements related to online course structure, both groups of respondents exhibited about the same level of agreement with all statements. Both groups of respondents had similar levels of agreement that the interaction with the instructor is greater in a traditional class as compared with a comparable online class. Both groups agreed about the difficulty of tests in an online course; likewise, both groups agreed that the technology required to take an online class enhances the experience. Finally, both groups of 
respondents agreed that meeting with students outside of class was important; however, the 2001-2002 respondents had a significantly higher level of agreement than did the 2005 students. In sum, it appears that students continue to have some questions about the overall appeal of online courses.

Before offering online courses, professors and/or administrators might wish to more effectively communicate some of the benefits associated with these courses in order to reduce resistance to them. A detailed description of the course and what it entails should be made available to prospective students well in advance of the time that the course will be offered. At any rate, while the success of online courses might not depend entirely on communicating what such courses involve, certainly some of the resistance to them could be alleviated by setting up a long-range plan which would focus on making more knowledge about these courses available to future students.

\section{Suggestions For Administrators}

Administrators should be advised as to the results of this study so that they can consider offering other distance learning courses, based on these results. The key is in using these results to effectively communicate the benefits stated by students who have taken online courses previously; this should help alleviate students' fears associated with taking online courses. Additionally, administrators should be advised about the various differences in perceptions of the other demographic groups, so they can take steps to enhance the effectiveness of distance learning courses to females, younger students, and non-business students. Previous studies have shown significant differences exist, by gender, age, major area of study, and prior online experience, in student perceptions (Tanner, Noser, Langford, 2003; Tanner, Noser, Fuselier, Totaro, 2004; Tanner, Noser, Fuselier, Totaro, 2004). Also, although it is not one of the objectives of this study, administrators should make certain they have the infrastructure to offer more distance learning courses prior to implementing any marketing strategies based on the results of this study.

\section{Suggestions For Faculty}

Given the results of this study, information sessions could be offered to faculty prior to their venturing into the online realm illustrating the expected benefits from taking part in one or more distance learning classes. (A similar course of action could be taken during advising for students. These steps may help to alleviate anxiety or fears concerning distance-learning held by faculty and/or students.) Faculty should take the results of this study into consideration when preparing future distance learning courses. They should be prepared for the fact that males and females, as well as the other demographic groups, have different perceptions as to what is involved in a distance learning course, and should take steps to overcome resistance by those groups with negative perceptions. Faculty members should pay particularly close attention to the differences in perceptions of those students with prior online course experience versus those with no experience, if they are to design their courses in such a way as to attract future "first-time" online students. If possible, teachers could use former students to serve as "walking, talking advertisements" of the virtues of distance-learning courses.

\section{Suggestions For Students}

Especially important to students are the perceptions of respondents with prior online course experience, because their opinions are the ones upon which other students should focus when deciding to take such courses. Also, the insights/opinions of respondents with positive perceptions in the other demographic groups should be communicated to prospective distance learning students, in order that they may be better prepared when they take these courses.

\section{Related Research Opportunities}

Given that these findings are for student perceptions only, it would seem that future research should survey perceptions of faculty members, both those who have taught and those who have not taught online courses. Then, perhaps comparisons could be made between student and faculty perceptions. Also, most of the respondents in the current study are undergraduate students; perhaps a related study could focus on graduate students, again with the ultimate goal of comparing perceptions between all three groups. In addition, a study that focuses on the perceptions 
of administrators, followed by a comparison between administrators and faculty, might prove useful. Finally, additional updates, similar to the current one, should continue to be made, which would help students, faculty, and administrators maintain a realistic understanding of the continuing opportunities associated with online distance learning.

\section{REFERENCES}

1. Allen, M., Bourhis, J., Burrell, N., \& Mabry, E. (2002). Comparing Student Satisfaction with Distance Education to Traditional Classrooms in Higher Education: A Meta-analysis. The American Journal of Distance Education, 16(2): 83-97.

2. Chen, Y., Lou, H., and Luo, W. (2001). Distance-Learning Technology Adoption: A Motivation Perspective. Journal of Computer Information Systems, Winter: 38-43.

3. Daniel, J. (1997). Why Universities Need Technology Strategies. Change, 29: 10-17.

4. Howland, J., \& Moore, J. (2002). Student Perceptions as Distance Learners in Internet-Based Courses Distance Education, 23(2): 183-195.

5. Lewis, L., Alexander, D., \& Farris E. (1997). Distance Education in Higher Education Institutions (NCES 98-062): Washington, D.C.: U.S. Department of Education Office of Educational Technology National Center for Education Statistics.

6. Parker, M. (2003). Technology-enhanced e-Learning: Perceptions of First Year Information Systems Students at the Cape Technikon, Proceedings of the South African Institute of Computer Scientists and Information Technologists, SAICSIT 2003: 316-319.

7. Phillips, V. (1998). Online Universities Teach Knowledge Beyond the Books. HR Magazine, 43(8): 121128.

8. $\quad$ Roberts, B. (1998). Training Via Desktop. HR Magazine, 43(9): 98-104.

9. Tanner, J., Noser, T., Fuselier, J., \& Totaro, M. (2004). The Online 'Classroom': Differences in Perception Between Business Students and Non-Business Students, Journal of College Teaching \& Learning, 1(3):3744.

10. Tanner, J., Noser, T., Fuselier, J., \& Totaro, M. (2004). The Online 'Classroom': What Do Students Think? Journal of Informatics and Educational Research, 6(1): 43-54.

11. Tanner, J., Noser, T., \& Langford, H. (2003). Perceptions of Undergraduate Business Students Toward Online Courses In Higher Education Expanded and Revisited: Do Gender, Age, And/Or Past Experiences Make A Difference? Journal of Business \& Economics Research, 1(2):13-20.

12. Tanner, J., Langford, H., \& Walker D. (2001). Attitudes and Perceptions of Undergraduate Business Students Toward Distance Education, Proceedings of the International Business and Economics Research Conference, October 10, 2001, Reno, NV.

13. Webster, J., \& Hackley, P. (1997). Teaching Effectiveness in Technology Mediated Distance Learning. Academy of Management Journal, 40 (6): 1282-1309. 


\section{Online Course Questionnaire}

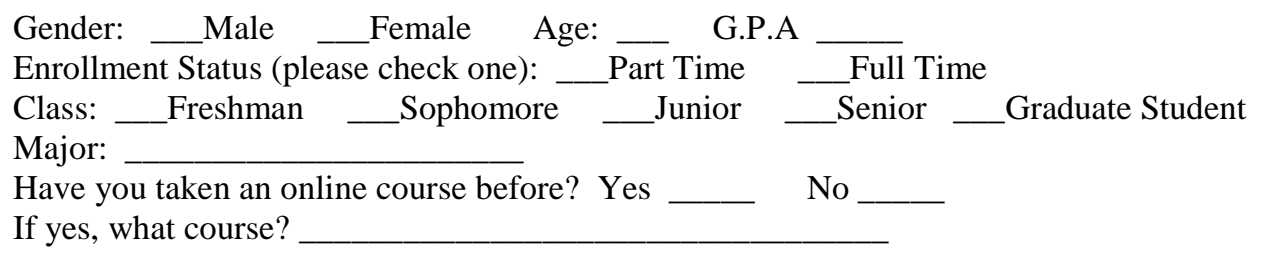

Please indicate your level of agreement or disagreement with the following statements by placing the appropriate number next to the statement. Please use the following numbering system:

$$
\begin{aligned}
& 1=\text { Strongly Agree } \\
& 2=\text { Agree } \\
& 3=\text { Neither Agree nor Disagree } \\
& 4=\text { Disagree } \\
& 5=\text { Strongly Disagree }
\end{aligned}
$$

1. One of the advantages of taking this course online is the fact that class times were flexible.

2. I believe that a class in liberal arts, such as history, psychology, sociology, etc., would work well if offered online

3. The interaction/lectures with the instructor is greater in a regular classroom setting than in an online class

4. Math and other quantitative courses are among the most difficult of all my college courses.

5. I believe taking a course online allows studying at your own pace....

6. In my opinion, management courses should not be offered online.....

7. Meeting with other students outside of class is important to me.......

8. I would take a statistics or other quantitative class online if it was offered.

9. The fact that this course had no structured classroom-type environment appeals to me.

10. In the future, I will take as many courses as possible online. .........

11. I would miss the interaction with other students in an online class....

12. The textbook is more important in an online class....................

13. Tests in an online class are more difficult............................

14. Online classes require the students to teach themselves the material...

15. The technology required to take an online course increases the value

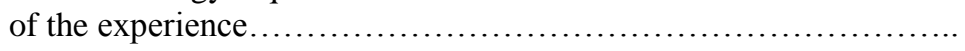

16. Online classes require the student to be self-disciplined. 